\title{
The Risk Factors of Gestational Diabetes Mellitus: A Systematic Review and Meta-Analysis Study
}

\author{
Faezeh Kiani ${ }^{1}$, Marzieh Saei Ghare $\mathrm{Naz}^{2}$, Fatemeh Sayehmiri ${ }^{3}$, Kourosh Sayehmiri ${ }^{4}$, Hakimeh Zali ${ }^{*}$
}

\begin{abstract}
Objectives: Gestational diabetes mellitus (GDM) is the most common medical complication of pregnancy. If remains uncontrolled, it can cause lots of complications for both mother and fetus. The aim of this study is to investigate the risk factors of GDM in Iran using a meta-analysis study.

Methods: Different databases including all national scientific (Iranmedex, SID, Magiran, Irandoc, and Medlib) and international (PubMed/Medline, Scopus, and ISI Web of Knowledge) databases were searched for published data on GDM risk factors in Iran. A total of 21 relevant articles from 2001 to 2015 were finally analyzed. Data synthesis was performed based on the random effects model. Data were analyzed using R software and STATA.

Results: A total of 1658 pregnant women with average age of 29.15 years old were investigated. The mean body mass index (BMI) of the subjects was 27.53. The most common risk factors for GDM were: high age 64\% (95\% CI: 53-76), excess weight and obesity $47 \%$ (95\% CI: 40-54), family history of diabetes $31 \%$ (95\% CI: 26-36), history of abortion $22 \%$ (95\% CI:16-27), history of glycosuria $12 \%$ (95\% CI: 4-19), history of macrosomia 10\% (95\% CI: $6-13$ ), delivery $\geq 5$ case $10 \%$ (95\% CI: $2-17)$, history of gestational hypertension 5\% (95\% CI: 1-8), history of preeclampsia 4\% (95\% CI:2 -7), history of diabetes in pregnancy $4 \%$ (95\% CI: 1-8), history of stillbirths 3\% (95\% CI: $2-5$ ), delivery <37 weeks 3\% (95\% CI: $0-6)$, previous congenital malformations $1 \%$ (95\% CI: 0-2) and previous neonatal death $1 \%$ (95\% CI: $0-2)$.

Conclusion: Considering that approximately $40 \%$ of pregnancy diabetes cases will turn into diabetes over the coming years, controlling the risk factors can reduce the incidence of diabetes in pregnancy.

Keywords: Gestational diabetes, risk factors, meta-analysis, Iran
\end{abstract}

\section{Introduction}

Gestational diabetes mellitus (GDM) refers to elevated blood sugar level that is firstly diagnosed during pregnancy (1). GDM is the most common metabolic disorder in pregnancy (2) which leads to severe complications for mother and fetus such as preeclampsia, premature membrane rupture, preterm delivery, cesarean, fetal macrosomia and poly hydramnios or damages during delivery including dislocation of the shoulder, bone fractures, nerve paralysis, low birth weight and fetal metabolic disorders (3-9). Results of studies on children of mothers with gestational diabetes indicate that these children are exposed to greater risk levels of obesity, increased body mass index (BMI), excess weight, insulin resistance, hypertension, renal disease, and type 2 diabetes (5,10-13). Some investigations revealed that GDM are more common in the communities with a higher prevalence of type 2 diabetes; however, the risk and onset of the disease are quite variable (14-16). In addition, the risk of cardiovascular diseases and type 2 diabetes have been proven in women with history of gestational diabetes $(10,17)$.

The most important risk factors for gestational diabetes include age, high BMI, previous history of gestational diabetes, positive family history in first degree relatives, family history of diabetes, history of disorders in previous pregnancies (such as miscarriage, stillbirth, macrosomia, preterm delivery, eclampsia, preeclampsia, etc), belonging to a particular race, smoking, and short stature of mothers $(8,9)$. GDM is one of the most common complications of pregnancy in the United States occurring in about 7\% (more than 200000 each year) of all pregnancies (18). Despite numerous studies on risk factors for gestational diabetes in American and European populations, limited studies have been conducted in this field in Iran (19). Considering the numerous and serious complications of this disease, lack of appropriate measures for the prevention, control and treatment, leads to countless limitations and problems for individuals at risk (20). Therefore, this investigation aims to assess risk factors associated with gestational diabetes by various studies in Iran using the meta-analytical method. 


\section{Methods}

\section{Search Strategy}

We conducted a systematic literature search for published papers on gestational diabetes risk factors in Iran in the national and international journals and students' theses. The databases include national scientific (Iranmedex, SID, Magiran, Irandoc, and Medlib) and international (PubMed/Medline, Scopus, and ISI Web of Knowledge) databases. Searching was done using keywords like gestational diabetes mellitus, gestational age, high age, overweight and obese, stillbirth, abortion, family history of diabetes, fetal macrosomia, preeclampsia, gestational diabetes history, Glycosuria, gestational hypertension, Iran, and their combinations and their corresponding Persian keywords. For any of the risk factors, relevant keywords were searched in women of reproductive age. The study was limited to papers in English and Persian languages published between 1990 and 2015. To expand the search, wildcard symbol '*' was used and the search words or phrases were combined using Boolean operators. We also searched bibliographies of retrieved articles for additional references. In addition, the references from selected articles were examined as a further search tool. A manual search for additional studies was carried out using references cited in the reviewed articles.

\section{Study Selection}

Titles and abstracts related to GDM risk factors in Iran were screened and when decision could not be made based the abstract alone, full articles were acquired for the other stage of screening. When necessary, authors were contacted for additional information. Studies presenting insufficient data, meta-analyses or systematic reviews and duplicate publication of the same study were omitted.

\section{Data Extraction}

The main information of the included articles was summarized by 2 authors into the data collection forms, and then these data were entered into Microsoft Excel. For all studies, the following data were extracted: first author, year of publication, location, sample size, mean age of the patients and the risks factors of diabetes during pregnancy. Data in this review were obtained only from studies that had used random sampling and a standard measurement technique for data collection.

\section{Statistical Analysis}

Variance of each study was calculated according to the binomial distribution. Studies were combined based on their sample sizes, mean and standard deviation. The difference between the average variance of the normal distribution was calculated using the formula of two integrated variance. Due to the heterogeneity in the studies, random effect model was employed in combining studies; and heterogeneity assessment was carried out by Cochrane Q test and $\mathrm{I}^{2}$ statistics. $P$ value less than 0.05 was considered as a significant heterogeneity test. Depending on the analyzed data, there was not a need to determine publication bias and drawing the funnel plot. Statistical analyses were performed by STATA version 12 .

\section{Results}

According to initial search keywords related to risk factors of GDM in Iran in different sources, 106 articles were found. In a secondary screening, 17 of them were excluded based on title and abstract evaluation, 8 of them were excluded because of duplication and 81 were retained for detailed full-text evaluation. So, finally 81 relevant articles containing original data were fully examined. After fulltext evaluation, we excluded another 60 articles (Of these, thirty-nine did not report the risk factors of GDM, nine were retrospective and review studies, twelve presented quantitative data that could not be analyzed). Finally 21 articles published from 2001 to 2015 met the inclusion criteria of the study (Figure 1). The characteristics of the 21 studies included (21-41) in this meta-analysis are summarized in Table 1.

A total of 1658 pregnant women with average age of 29.15 years old were investigated. Their mean BMI were 27.53 which are located at the overweight range. Table 1 presents the risk factors of GDM and the prevalence each of them in included articles. The estimated prevalence of the GDM risk factors in the country according to meta-analysis is shown in Table 2 . As it can be seen, the prevalence of high age was calculated as $64 \%$ (with a confidence interval of 95.3\%: 53-76) (Figure 2). In seven studies $(23,25-27,33,34,36)$ ages $\geq 25$ were considered as risk factors of gestational diabetes, whereas four studies $(24,28,29,32)$ suggested ages $\geq 30$ as the risk factor of gestational diabetes. The prevalence of overweight and obesity in our female subjects were $47 \%$ (with a CI of 78.6\%: 40-54) (Figure 3). Meta-analysis showed a 3\% prevalence of stillbirths (with a CI of 43\%: 2-5), 22\% history of abortion (with a CI of 78.3\%:16-27) (Figure 4), $31 \%$ family history of diabetes (with a CI of 75.6\%: 26-36) (Figure 5), 5\% history of gestational hypertension (with a CI of $70.6 \%$ : $1-8$ ), $4 \%$ history of preeclampsia (with a CI of $78.5 \%: 2-7$ ), $4 \%$ history of diabetes in pregnancy (with a CI of $51.4 \%: 1-8$ ), $10 \%$ history of macrosomia (with a CI of $83.4 \%$ : $6-13$ ), $12 \%$ glycosuria (with a CI of $93 \%$ : $4-19$ ), $1 \%$ previous congenital malformations (with a CI of $0.0 \%$ : $0-2$ ), $1 \%$ previous neonatal death (with a CI of $0.0 \%$ : $0-2$ ), $3 \%$ delivery $<37$ weeks (with a $\mathrm{Ci}$ of $65 \%$ : $0-6$ ) and $10 \%$ delivery $\geq 5$ case (with a Ci of 643\%: 2-17 (Table 2).

The relationship between GDM risk factors and year of study was calculated based on the Meta regression model. Interpretation of meta-regression showed that there was no significant relationship between GDM risk factors and the year of study $(P \geq 0.05)$. For example in Figure 6 the prevalence of history of abortion was checked with its year. As it can be seen, there was no significant relationship in this regard $(P=0.59)$.

According to the publication bias figure, the effect of bias in these studies was not significant. For example Figure 7 presents the funnel plot of the included trials related to prevalence of fetal macrosomia. Regression analysis of this plot indicated no significant asymmetry $(P$ 
Table 1. The Characteristics of different Studies Related to Risk Factors of Gestational Diabetes

\begin{tabular}{|c|c|c|c|c|c|c|c|c|c|c|c|c|c|c|c|c|}
\hline \multirow[b]{2}{*}{$\begin{array}{l}\text { Study location } \\
\text { (Ref) }\end{array}$} & \multirow[b]{2}{*}{$\begin{array}{l}\text { Year of } \\
\text { study }\end{array}$} & \multirow[b]{2}{*}{$\begin{array}{l}\text { Sample } \\
\text { size }\end{array}$} & \multicolumn{14}{|c|}{ The risk factors of GDM and the its prevalence, $95 \% \mathrm{Cl}$ [Lower - Upper] } \\
\hline & & & $\begin{array}{l}\text { High } \\
\text { age }\end{array}$ & $\begin{array}{l}\text { Overweight } \\
\text { and obese }\end{array}$ & $\begin{array}{l}\text { History of } \\
\text { stillbirth }\end{array}$ & $\begin{array}{l}\text { History of } \\
\text { abortion }\end{array}$ & $\begin{array}{c}\text { Family } \\
\text { history } \\
\text { of } \\
\text { diabetes }\end{array}$ & $\begin{array}{c}\text { History of } \\
\text { hypertension }\end{array}$ & $\begin{array}{l}\text { History of } \\
\text { preeclampsia }\end{array}$ & $\begin{array}{l}\text { History of } \\
\text { Gestational } \\
\text { diabetes }\end{array}$ & $\begin{array}{l}\text { Previous } \\
\text { foetal } \\
\text { macrosomia }\end{array}$ & $\begin{array}{l}\text { History of } \\
\text { Glycosuria }\end{array}$ & $\begin{array}{l}\text { Delivery } \\
\geq 5 \text { case }\end{array}$ & $\begin{array}{l}\text { Delivery } \\
<37 \text { wk }\end{array}$ & $\begin{array}{c}\text { Previous } \\
\text { congenital } \\
\text { malformations }\end{array}$ & $\begin{array}{c}\text { Previous } \\
\text { neonatal } \\
\text { death }\end{array}$ \\
\hline Tehran (21) & $\begin{array}{l}1992- \\
1994\end{array}$ & 27 & & $15 \%[1,28]$ & & & $\begin{array}{c}22 \% \\
{[7,38]}\end{array}$ & $\begin{array}{c}11 \% \\
{[-1,23]}\end{array}$ & & & & $\begin{array}{c}11 \% \\
{[-1,23]}\end{array}$ & & & & \\
\hline Tehran (22) & $\begin{array}{l}1997- \\
2001\end{array}$ & & & & $\begin{array}{c}5 \% \\
{[-5,15]}\end{array}$ & $\begin{array}{c}42 \% \\
{[20,64]}\end{array}$ & $\begin{array}{c}232 \% \\
{[11,53]}\end{array}$ & & & & $\begin{array}{c}16 \% \\
{[-1,32]}\end{array}$ & & $\begin{array}{c}10 \% \\
{[-3,24]}\end{array}$ & & & \\
\hline Bushehr (23) & $\begin{array}{l}1998- \\
2000\end{array}$ & 64 & $\begin{array}{c}84 \% \\
{[76,93]}\end{array}$ & $\begin{array}{c}72 \% \\
{[61,83]}\end{array}$ & $\begin{array}{c}10 \% \\
{[3,17]}\end{array}$ & & $\begin{array}{c}31 \% \\
{[20,43]}\end{array}$ & $\begin{array}{c}10 \% \\
{[2,17]}\end{array}$ & & $\begin{array}{c}3 \% \\
{[-1,8]}\end{array}$ & $\begin{array}{c}16 \% \\
{[7,25]}\end{array}$ & & & & $\begin{array}{c}3 \% \\
{[-1,8]}\end{array}$ & $\begin{array}{c}3 \% \\
{[-1,8]}\end{array}$ \\
\hline Shahrood (24) & $\begin{array}{l}1999- \\
2000\end{array}$ & 63 & $\begin{array}{c}41 \% \\
{[29,53]}\end{array}$ & $\begin{array}{c}43 \% \\
{[31,55]}\end{array}$ & $\begin{array}{c}2 \% \\
{[-1,5]}\end{array}$ & $\begin{array}{c}6 \% \\
{[0,12]}\end{array}$ & $\begin{array}{c}43 \% \\
{[31,55]}\end{array}$ & $\begin{array}{c}0 \% \\
{[-3,3]}\end{array}$ & $\begin{array}{c}3 \% \\
{[-1,8]}\end{array}$ & & $\begin{array}{c}21 \% \\
{[11,31]}\end{array}$ & $\begin{array}{c}19 \% \\
{[9,29]}\end{array}$ & & & $\begin{array}{c}2 \% \\
{[-1,5]}\end{array}$ & $\begin{array}{c}2 \% \\
{[-1,5]}\end{array}$ \\
\hline Tehran (25) & $\begin{array}{l}2000- \\
2001\end{array}$ & 107 & $\begin{array}{c}89 \% \\
{[87,90]}\end{array}$ & $\begin{array}{c}44 \% \\
{[42,46]}\end{array}$ & $\begin{array}{c}1 \% \\
{[-1,3]}\end{array}$ & $\begin{array}{c}14 \% \\
{[7,21]}\end{array}$ & $\begin{array}{c}28 \% \\
{[26,30]}\end{array}$ & & $\begin{array}{l}0.0 \% \\
{[-2,2]}\end{array}$ & & $\begin{array}{c}3 \% \\
{[2,4]}\end{array}$ & & & & $\begin{array}{c}1 \% \\
{[-1,3]}\end{array}$ & \\
\hline Tehran (26) & $\begin{array}{l}2001- \\
2002\end{array}$ & 114 & $\begin{array}{c}27 \% \\
{[19,35]}\end{array}$ & $\begin{array}{c}37 \% \\
{[28,46]}\end{array}$ & & $\begin{array}{c}25 \% \\
{[17,33]}\end{array}$ & $\begin{array}{c}33 \% \\
{[25,42]}\end{array}$ & & $\begin{array}{c}4 \% \\
{[1,8]}\end{array}$ & & $\begin{array}{c}25 \% \\
{[17,33]}\end{array}$ & $\begin{array}{c}34 \% \\
{[25,43]}\end{array}$ & $\begin{array}{c}15 \% \\
{[8,21]}\end{array}$ & $\begin{array}{c}8 \% \\
{[3,13]}\end{array}$ & & \\
\hline Bandarabbas (27) & $\begin{array}{l}2002- \\
2003\end{array}$ & 62 & $\begin{array}{c}73 \% \\
{[61,84]}\end{array}$ & $\begin{array}{c}50 \% \\
{[38,62]}\end{array}$ & $\begin{array}{c}2 \% \\
{[-2,5]}\end{array}$ & $\begin{array}{c}18 \% \\
{[8,27]}\end{array}$ & $\begin{array}{c}13 \% \\
{[5,21]}\end{array}$ & $\begin{array}{c}2 \% \\
{[-2,5]}\end{array}$ & $\begin{array}{c}3 \% \\
{[-1,8]}\end{array}$ & & $\begin{array}{c}5 \% \\
{[-1,10]}\end{array}$ & $\begin{array}{c}5 \% \\
{[-1,10]}\end{array}$ & $\begin{array}{c}5 \% \\
{[-1,10]}\end{array}$ & $\begin{array}{c}2 \% \\
{[-2,5]}\end{array}$ & & \\
\hline Esfahan (28) & $\begin{array}{l}2002- \\
2003\end{array}$ & 73 & $\begin{array}{c}53 \% \\
{[42,65]}\end{array}$ & $\begin{array}{c}59 \% \\
{[48,70]}\end{array}$ & & & $\begin{array}{c}13 \% \\
{[5,20]}\end{array}$ & & & & & & & & & \\
\hline Ardebel (29) & 2003 & 8 & $\begin{array}{c}50 \% \\
{[15,85]}\end{array}$ & $\begin{array}{c}38 \% \\
{[4,71]}\end{array}$ & & & & & & & & & & & & \\
\hline Tehran (30) & $\begin{array}{l}2003- \\
2006\end{array}$ & & $\begin{array}{c}57 \% \\
{[50,64]}\end{array}$ & & & & & & & & & & & & & \\
\hline Ahvaz (31) & $\begin{array}{l}2004- \\
2006\end{array}$ & 50 & & & $\begin{array}{c}2 \% \\
{[-2,6]}\end{array}$ & $\begin{array}{c}30 \% \\
{[17,43]}\end{array}$ & & & & $\begin{array}{c}10 \% \\
{[2,18]}\end{array}$ & $\begin{array}{c}6 \% \\
{[-1,13]}\end{array}$ & & & & $\begin{array}{c}0 \% \\
{[-4,4]}\end{array}$ & \\
\hline Tehran (32) & $\begin{array}{l}2007- \\
2008\end{array}$ & & $\begin{array}{c}48 \% \\
{[43,53]}\end{array}$ & $\begin{array}{c}49 \% \\
{[44,54]}\end{array}$ & $\begin{array}{c}4 \% \\
{[2,5]}\end{array}$ & & $\begin{array}{c}38 \% \\
{[33,43]}\end{array}$ & & $\begin{array}{c}8 \% \\
{[5,11]}\end{array}$ & & $\begin{array}{c}17 \% \\
{[13,21]}\end{array}$ & $\begin{array}{c}7 \% \\
{[4,9]}\end{array}$ & & & $\begin{array}{c}1 \% \\
{[0,2]}\end{array}$ & $\begin{array}{c}2 \% \\
{[0,3]}\end{array}$ \\
\hline
\end{tabular}




\section{Table 1. Continued}

\begin{tabular}{|c|c|c|c|c|c|c|c|c|c|c|c|c|c|c|c|}
\hline Kermanshah (33) & 2008 & 59 & & $\begin{array}{c}44 \% \\
{[31,57]}\end{array}$ & $\begin{array}{c}5 \% \\
{[-1,11]}\end{array}$ & $\begin{array}{c}32 \% \\
{[20,44]}\end{array}$ & $\begin{array}{c}37 \% \\
{[25,50]}\end{array}$ & $\begin{array}{c}5 \% \\
{[-1,11]}\end{array}$ & $\begin{array}{c}2 \% \\
{[-2,5]}\end{array}$ & $\begin{array}{c}7 \% \\
{[0,13]}\end{array}$ & $\begin{array}{c}5 \% \\
{[-1,11]}\end{array}$ & & & & \\
\hline Karaj (34) & 2008 & 124 & $\begin{array}{c}79 \% \\
{[72,86]}\end{array}$ & & & $\begin{array}{c}18 \% \\
{[11,24]}\end{array}$ & $\begin{array}{c}32 \% \\
{[24,41]}\end{array}$ & & & & $\begin{array}{c}9 \% \\
{[4,14]}\end{array}$ & & & & \\
\hline $\begin{array}{l}\text { Tehran } \\
\text { (35) }\end{array}$ & $\begin{array}{l}2008- \\
2009\end{array}$ & 20 & & $\begin{array}{c}45 \% \\
{[31,57]}\end{array}$ & & & & & & & $\begin{array}{c}5 \% \\
{[-5,15]}\end{array}$ & & & & \\
\hline $\begin{array}{l}\text { Babol } \\
\text { (36) }\end{array}$ & $\begin{array}{l}2010- \\
2011\end{array}$ & 191 & $\begin{array}{c}76 \% \\
{[67,86]}\end{array}$ & $\begin{array}{c}52 \% \\
{[45,59]}\end{array}$ & $\begin{array}{c}9 \% \\
{[3,16]}\end{array}$ & $\begin{array}{c}37 \% \\
{[30,43]}\end{array}$ & $\begin{array}{c}45 \% \\
{[34,55]}\end{array}$ & $\begin{array}{c}12 \% \\
{[5,19]}\end{array}$ & $\begin{array}{c}17 \% \\
{[9,24]}\end{array}$ & & $\begin{array}{c}8 \% \\
{[4,12]}\end{array}$ & & & & \\
\hline Esfahan (37) & 2011 & & & & $\begin{array}{c}4 \% \\
{[0.0,8]}\end{array}$ & $\begin{array}{c}17 \% \\
{[9,25]}\end{array}$ & $\begin{array}{c}30 \% \\
{[20,40]}\end{array}$ & & $\begin{array}{c}3 \% \\
{[-1,6]}\end{array}$ & $\begin{array}{c}0.0 \% \\
{[-2,2]}\end{array}$ & $\begin{array}{c}1 \% \\
{[-1,4]}\end{array}$ & $\begin{array}{l}0.0 \% \\
{[-2,2]}\end{array}$ & $\begin{array}{c}1 \% \\
{[-1,4]}\end{array}$ & $\begin{array}{c}3 \% \\
{[-1,6]}\end{array}$ & $\begin{array}{c}0 \% \\
{[-2,2]}\end{array}$ \\
\hline Gorgan (38) & $\begin{array}{l}2011- \\
2012\end{array}$ & 62 & & & $\begin{array}{c}10 \% \\
{[3,17]}\end{array}$ & $\begin{array}{c}11 \% \\
{[3,19]}\end{array}$ & $\begin{array}{c}35 \% \\
{[24,47]}\end{array}$ & $\begin{array}{l}0.0 \% \\
{[-3,3]}\end{array}$ & & $\begin{array}{c}5 \% \\
{[-1,10]}\end{array}$ & $\begin{array}{c}10 \% \\
{[2,17]}\end{array}$ & & & & \\
\hline Rafsanjan (39) & $\begin{array}{l}2012- \\
2013\end{array}$ & & & & & & $\begin{array}{c}37 \% \\
{[19,55]}\end{array}$ & $\begin{array}{c}19 \% \\
{[4,33]}\end{array}$ & $\begin{array}{c}4 \% \\
{[2,7]}\end{array}$ & $\begin{array}{c}7 \% \\
{[-2,17]}\end{array}$ & $\begin{array}{c}15 \% \\
{[1,28]}\end{array}$ & & & & \\
\hline Hamedan (40) & 2014 & & $\begin{array}{c}70 \% \\
{[58,82]}\end{array}$ & & & & & & & & & & & & \\
\hline Zabol (41) & 2014 & & $\begin{array}{c}82 \% \\
{[64,100]}\end{array}$ & $\begin{array}{c}65 \% \\
{[42,87]}\end{array}$ & $\begin{array}{c}6 \% \\
{[-5,17]}\end{array}$ & $\begin{array}{c}35 \% \\
{[13,58]}\end{array}$ & $\begin{array}{c}29 \% \\
{[8,51]}\end{array}$ & & & $\begin{array}{c}12 \% \\
{[-4,27]}\end{array}$ & $\begin{array}{c}6 \% \\
{[5,17]}\end{array}$ & & & & \\
\hline
\end{tabular}




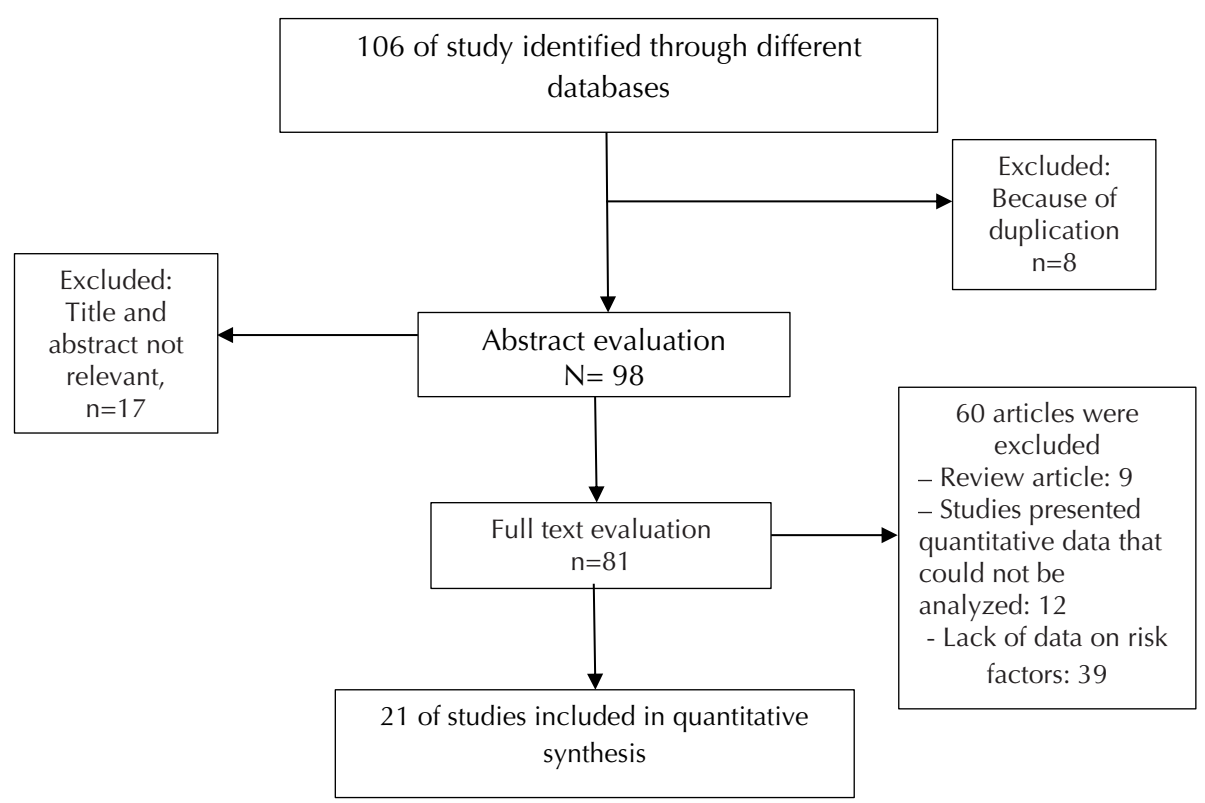

Figure 1. The Flowchart of Selected Articles for Final Analysis.

$=0.862)$ and thus no evidence of bias. In fact, most studies were located inside the funnel plot, thus demonstrating that the results of most relevant studies performed in Iran were included in the analysis (Figure 7).

\section{Discussion}

The relationship between some kind of risk factors such as high age, increase in body fat, race, and family history of diabetes, history of delivering a macrosomic infant, and previous history of impaired glucose tolerance with gestational diabetes has been proven $(42,43)$. Despite the numerous studies in this area field in different countries, a few studies have investigated the risk factors of gestational diabetes in Iran. In the present study, some of these risk factors were evaluated. The mean age of women with gestational diabetes was determined 29.15 which was similar to findings of Pirc et al, Hjelm et al and Seshiah et al (44-46). Another investigation in India reported the highest incidence of gestational diabetes in women older than 25 (47). Age of mother, is one of the factors contributing to the risk of pregnancy so that in two reproductive age ranges (less than 20 years and more than 35 years), problems and consequences of pregnancy are exacerbated (48-50). Age is a risk factor even in normal pregnancies and frequency of gestational diabetes increases with age, so that being older than 25 or 30 years old has been recognized as a risk factor for gestational diabetes (26). Results of the present investigation showed that the women in this study were at the gestational diabetes-risky age range. Variables of age and BMI have been reported

Table 2. The Risk Factors Prevalence of GDM in the Country According to the Included Study

\begin{tabular}{|c|c|c|c|c|c|c|}
\hline Risk Factors of GDM & $\begin{array}{c}\text { No of } \\
\text { Studies }\end{array}$ & Sample Size & $\begin{array}{c}\text { Prevalence (\%) } \\
\text { (Random Effects Model) }\end{array}$ & $95 \% \mathrm{Cl}$ & $I^{2}(\%)$ & $P$ Value \\
\hline High age & 13 & 483 & 64 & $53-76$ & $95.3 \%$ & 0.000 \\
\hline Overweight and obese & 13 & 780 & 47 & $40-54$ & $78.6 \%$ & 0.000 \\
\hline History of stillbirth & 12 & 658 & 3 & $2-5$ & $43.0 \%$ & 0.000 \\
\hline History of abortion & 12 & 832 & 22 & $16-27$ & $78.3 \%$ & 0.000 \\
\hline Family history of diabetes & 16 & 692 & 31 & $26-36$ & $75.6 \%$ & 0.000 \\
\hline Previous foetal macrosomia & 16 & 916 & 10 & $6-13$ & $83.4 \%$ & 0.000 \\
\hline History of preeclampsia & 9 & 489 & 4 & $2-7$ & $78.5 \%$ & 0.000 \\
\hline Gestational diabetes history & 7 & 235 & 4 & $1-8$ & $51.4 \%$ & 0.006 \\
\hline History of glycosuria & 6 & 266 & 12 & $4-19$ & $93.0 \%$ & 0.000 \\
\hline History of gestational hypertension & 8 & 466 & 5 & $1-8$ & $70.6 \%$ & 0.001 \\
\hline Previous congenital malformations & 6 & 272 & 1 & $0-2$ & $0.00 \%$ & 0.855 \\
\hline Previous neonatal death & 4 & 171 & 1 & $0-2$ & $0.00 \%$ & 0.524 \\
\hline Delivery $<37$ weeks & 3 & 119 & 3 & $0-6$ & $65.0 \%$ & 0.058 \\
\hline Delivery $\geq 5$ cases & 3 & 127 & 10 & $2-17$ & $64.1 \%$ & 0.062 \\
\hline
\end{tabular}




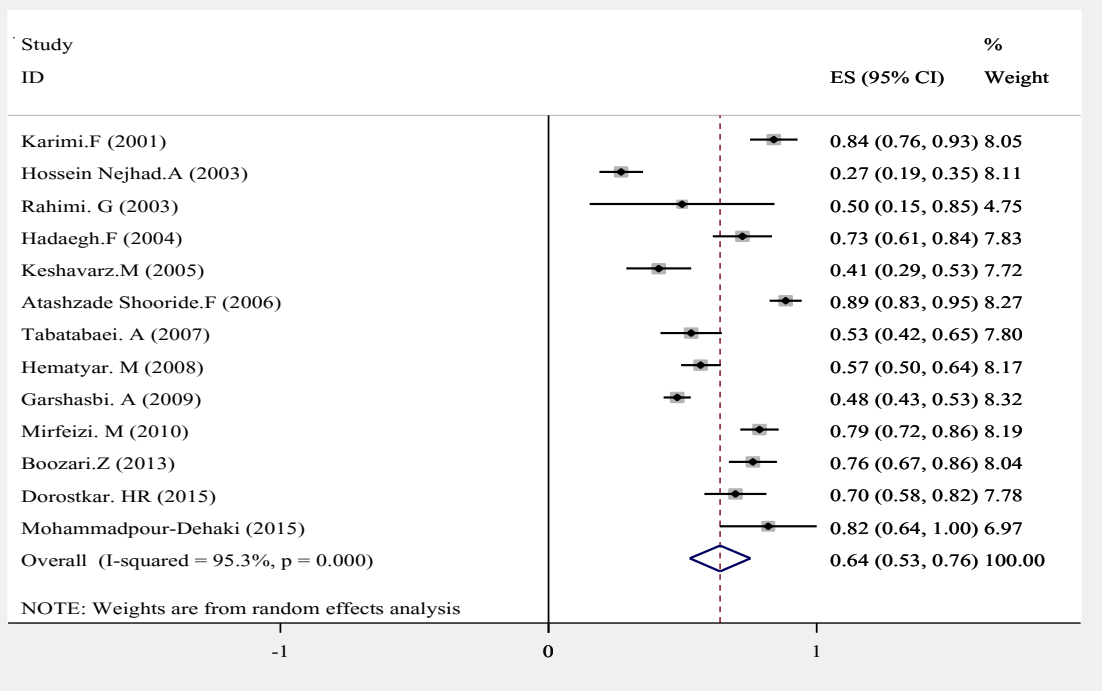

Figure 2. Prevalence of High Age and its $95 \% \mathrm{Cl}$. Midpoint of each line segment represents the estimated prevalence in the study. Rhombic mark shows the prevalence $\mathrm{n}$ Iran extracted from all studies.

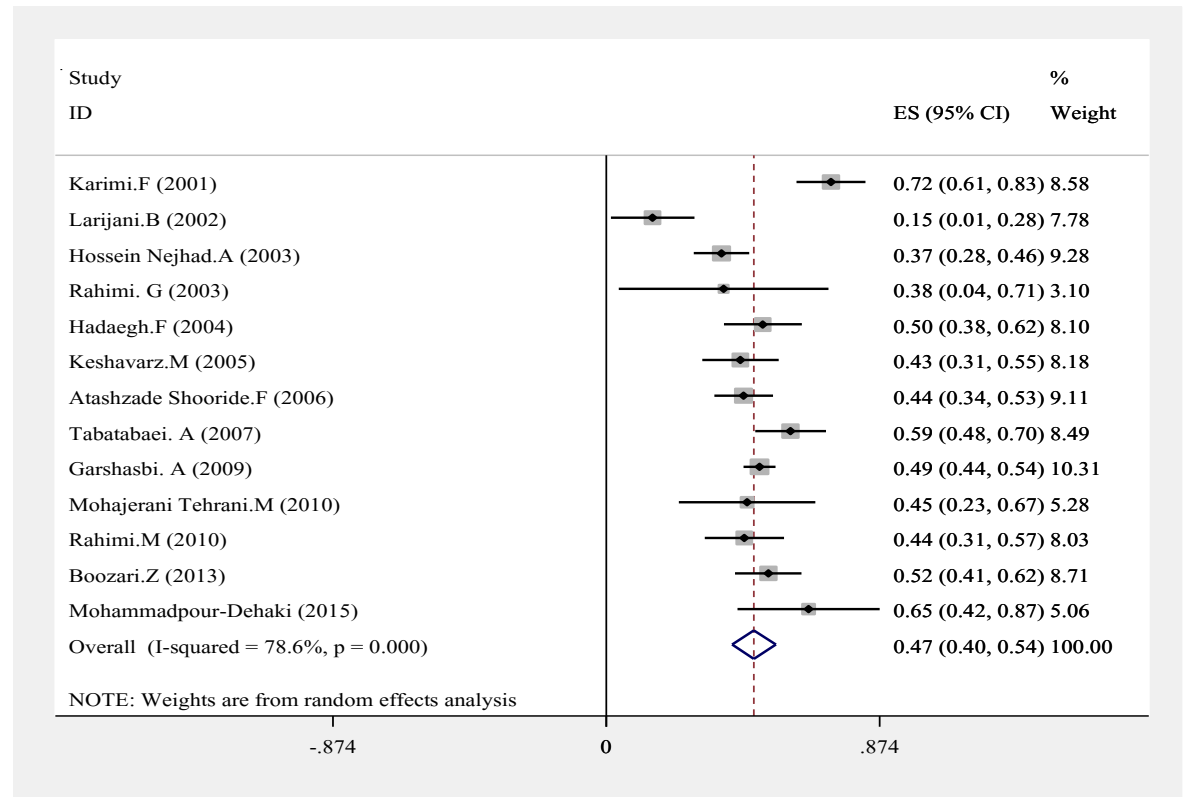

Figure 3. Prevalence of Overweight and Obese and its $95 \% \mathrm{Cl}$. Midpoint of each line segment represents the estimated prevalence in the study. Rhombic mark shows the prevalence in Iran extracted from all studies.

as two risk factors involved in gestational diabetes in a study conducted in Nigeria (51), which is similar with our findings. The relationship between maternal age and the prevalence of GDM has been also shown in Zargar et al study in Kashmir (52).

In the present study, the mean BMI of subjects was 27.53 which belongs to the overweight range. The investigation of O'Sullivan et al in Ireland highlighted high age and obesity as the contributing factors in increasing the prevalence of gestational diabetes (53). Also, Hisrt et al (4), in an investigation conducted on Vietnamese women, showed that increase in BMI leads to higher degrees of gestational diabetes which is consistent with our results. In several studies it has been found that there is a significant relationship between BMI and gestational diabetes (54), and they all suggest that weight gain is associated with development of diabetes. Relative insulin resistance and diabetes risk increase in obese individuals (55), and the impact of obesity on undesirable pregnancy outcome, such as history of stillbirth, abortion, macrosomia and preeclampsia, hypertension in pregnancy, and caesarean section have been reported in numerous studies (56-60). Considering this scientific fact that changes in BMI at the end of pregnancy is related to pre-pregnancy BMI and the weight gain of the mother during pregnancy, it has been accepted that weight gain and obesity are among the 


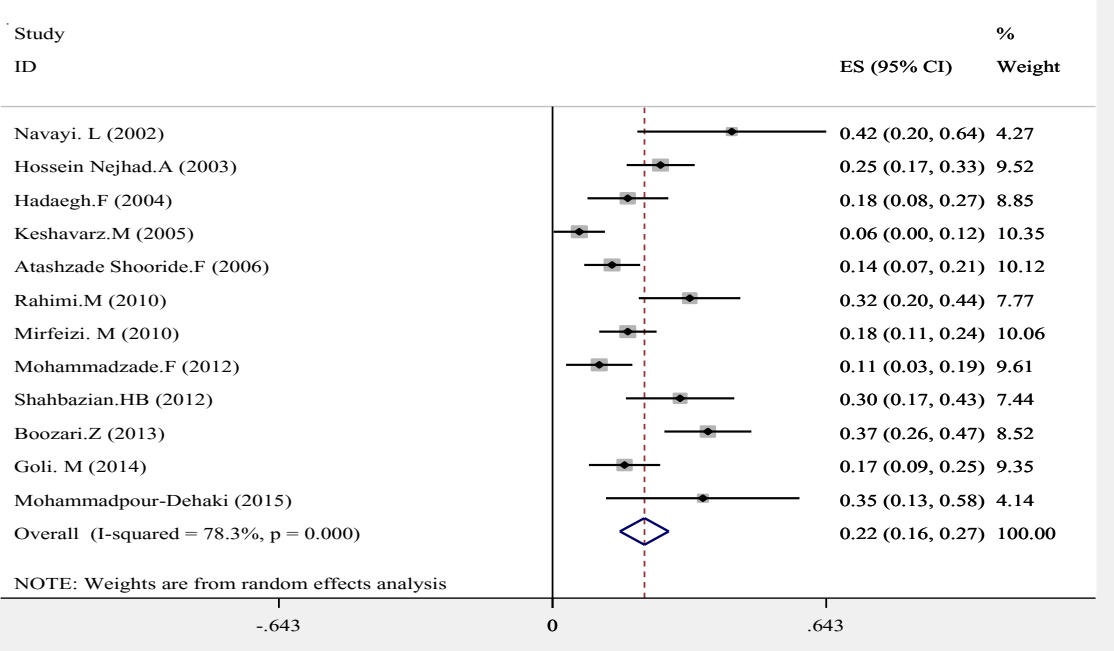

Figure 4. Prevalence of History of Abortion and its $95 \% \mathrm{Cl}$. Midpoint of each line segment represents the estimated prevalence in the study. Rhombic mark shows the prevalence in Iran extracted from all studies.

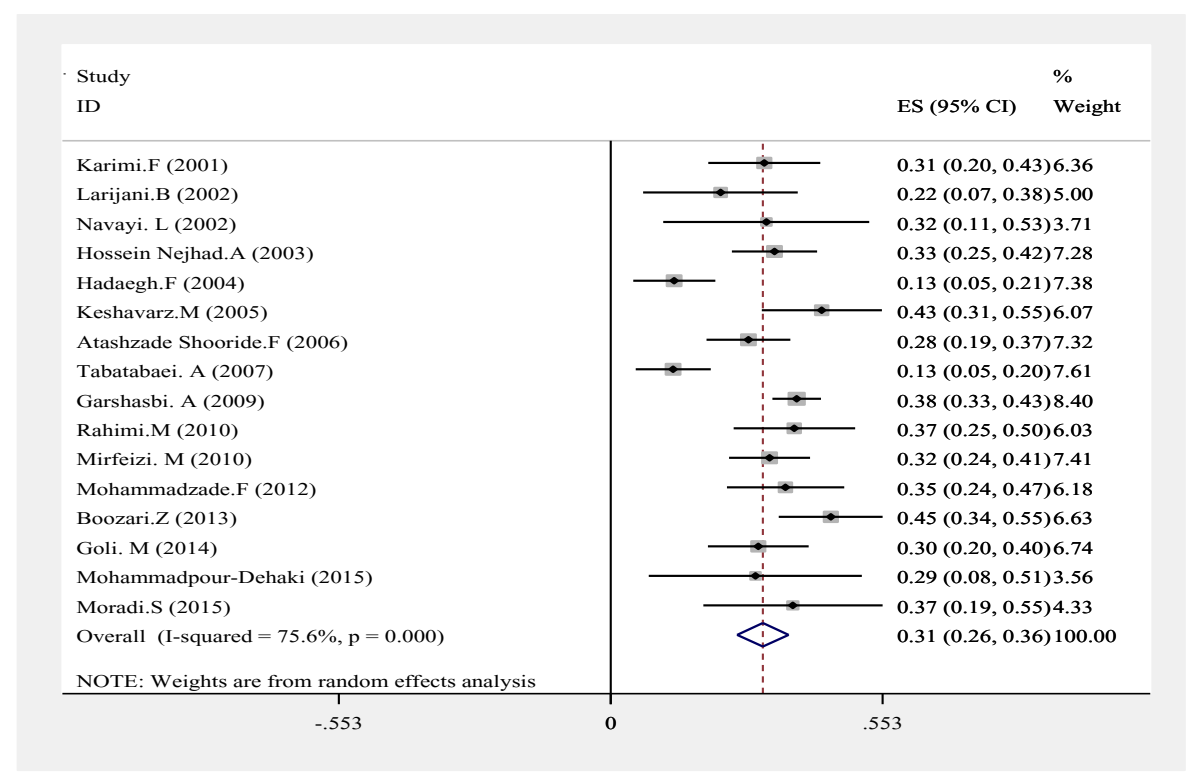

Figure 5. Prevalence of Family History of Diabetes and its $95 \% \mathrm{Cl}$. Midpoint of each line segment represents the estimated prevalence in the study. Rhombic mark shows the prevalence in Iran extracted from all studies.

risk factors for type 1 and 2 diabetes and also gestational diabetes $(61,62)$.

Also, history of abortion has been always considered as a risk factor for carbohydrate intolerance. This factor, at all levels of this disorder, shows a significant relationship, especially in gestational diabetes (63). The results of our study showed a high prevalence of abortion in women with gestational diabetes which is in agreement with previous studies $(64,65)$.

History of gestational diabetes or carbohydrate intolerance increases the likelihood of recurrence of this disease in future pregnancies. Some studies estimated approximately $30 \%$ to $70 \%$ of recurrence for this disease in future pregnancies (26). In the present study, prevalence of family history of diabetes were calculated as $31 \%$, which is higher than the results of Irving et al (66); they calculated $12 \%$ prevalence of gestational diabetes in women with a family history of diabetes (66). Our results suggest that family history of diabetes is a risk factor for gestational diabetes, which is in line with results of Johns et al (67). Also, Hisrt et al (4) reported a high prevalence of diabetes in the immediate family members of women with gestational diabetes which is consistent with the results of the present study. Family history of diabetes in first degree relatives is one of the most significant risk factors for gestational diabetes which further emphasizes the role of genetics in susceptibility toward this disease (68). On the other hand, Chan et al have suggested an independent role for this factor, especially in those older than 30 (69).

History of macrosomia was among the risk factors 


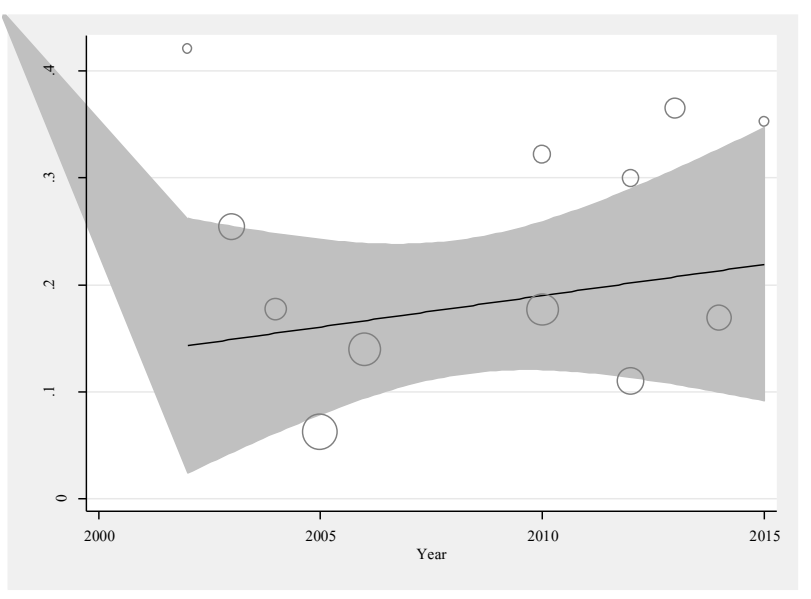

Figure 6. The Association Between Prevalence of History of Abortion and Year of Study Using Meta Regression

examined in this investigation. The incidence of neonatal macrosomia in patients with gestational diabetes is $20 \%$ $30 \%$ which is one of the most common complications of this disease. Some studies show that almost half of all cases of macrosomia were due to gestational diabetes. Therefore, delivery of a macrosomic infant appears to be a risk factor for developing the disease in subsequent pregnancies $(70,71)$. Saldana et al in a study conducted in North Carolina, reported high prevalence of macrosomia in women with gestational diabetes (72). Also, HernándezHerrera et al conducted an investigation in Spain on 85 infants of diabetic mothers; $31.7 \%$ of infants were macrosomic (73). $23.7 \%$ prevalence of macrosomia has been reported in the general population and in the group with gestational diabetes, macrosomia of $23.58 \%$ has been reported which is significantly higher than the normal. In the group with gestational diabetes, macrosomia of $23.58 \%$ has been reported which is significantly higher than the normal (74). Therefore, given the high prevalence of macrosomia in pregnancy outcome of patients with gestational diabetes, it seems that the history of previous macrosomia can be considered as a risk factor in women with gestational diabetes. Although the macrosomia is a major fetal complication, but due to the possible obstetrics involvement and cesarean in these mothers, is also considered as one of the high risk factors for mothers (75).

One of the main problems in women with gestational diabetes is their high blood pressure during pregnancy $(76,77)$. Gestational hypertension can be found in $10 \%$ of pregnant women and is associated with various fetal complications such as premature delivery, intrauterine growth retardation, asphyxia, embryos dying, placental abruption, acute liver and kidney failure, hemorrhage before and after delivery, and maternal mortality (7880 ). Women with gestational hypertension are at risk of seizures during pregnancy, metabolic syndrome, cardiovascular diseases, and strokes (78).

In the present study, the prevalence of glycosuria was $12 \%$. Glycosuria is a common finding in pregnancy. Increased glomerular filtration, along with impaired capacity for tubular reabsorption for the refined glucose, could be responsible for the emergence of glycosuria during pregnancy. Studies have shown that approximately 1 in 6 pregnant women was diagnosed with glycosuria (81). Glycosuria has shown an independent association with this disorder in many of the studies that have been conducted about gestational diabetes and impaired glucose tolerance (82).

Risk factors associated with gestational diabetes have been investigated in various studies. For example, in the studies of Hisrt et al (4), or Xiong et al (83), stillbirth, macrosomia, preeclampsia, family history of hypertension, and history of death at the birth have been proposed as risk factors of gestational diabetes. According to studies conducted in Australia and America, general risk factors for the gestational diabetes are similar and include high

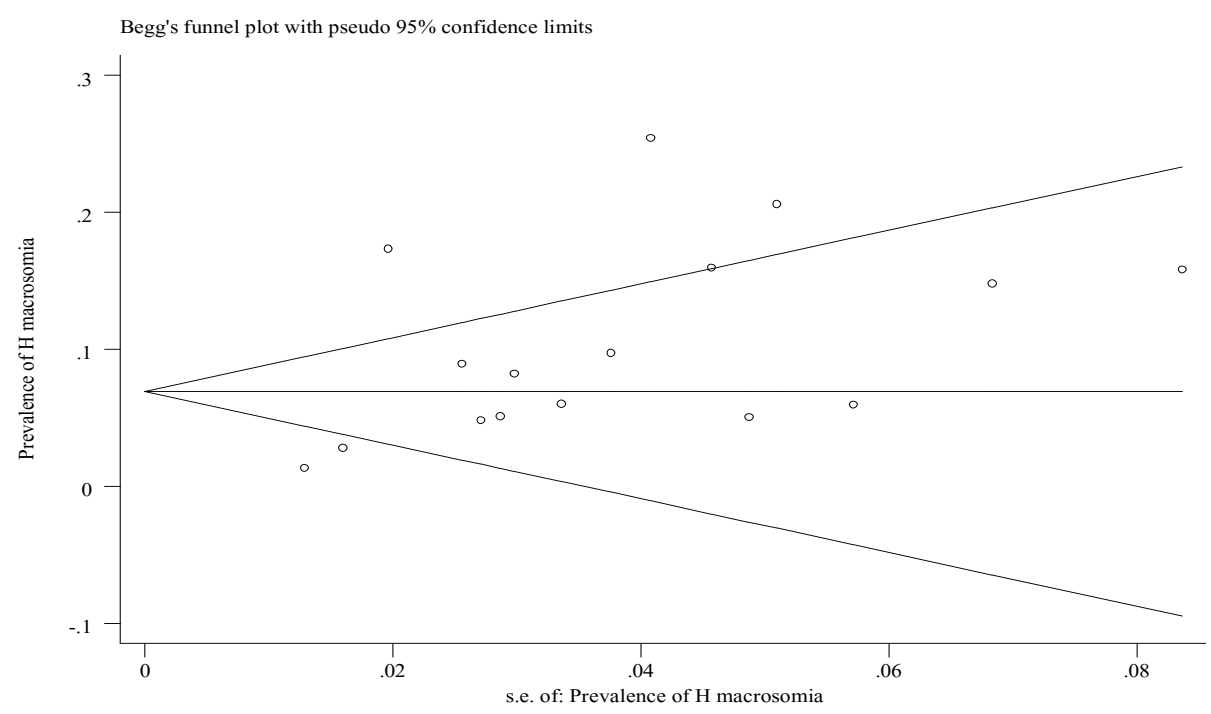

Figure 7. Funnel Plot for Publication Bias in the Risk Difference Analysis. 
BMI, positive family history of diabetes, history of macrosomia and glycosuria and high parity, and short stature of mothers $(9,84)$. Characteristics such as race, age, obesity, history of macrosomia and unexplained stillbirth puts women at the risk of gestational diabetes (85). Recently, in a review study, the necessity of conducting discussions regarding the risk factors such as number of pregnancies, history of hypertension, and other causes, has been further emphasized (42). Cheung et al, in a study conducted in Australia on the Asian pregnant women, showed that the risk factors of GDM in the Asian race are similar to Western countries (86).

\section{Conclusion}

The relationship between risk factors such as high age, increased body fat, race, family history of diabetes, history of delivering a macrosomic infant, history of impaired glucose tolerance etc in women with gestational diabetes have been proven in various studies. Given that about 40 percent of gestational diabetes cases can be converted to diabetes over the coming years, controlling these risk factors can reduce the incidence of diabetes during pregnancy. Therefore, the need to review and identify these risk factors seems necessary.

\section{Ethical Issues \\ Not applicable.}

\section{Conflict of Interests}

None to be declared.

\section{Financial Support}

None.

\section{Acknowledgements}

The authors extend their gratitude to the Student Research Committee, Ilam University of Medical Sciences for its support.

\section{References}

1. American Diabetes Association. Diagnosis and Classification of Diabetes Mellitus. Diabetes Care. 2010;33: 162-69. doi:10.2337/dc10-S062.

2. American Diabetes Association. Classification and diagnosis of diabetes mellitus. Diabetes Care. 2006;29 Suppl $1:$ S4-7.

3. Hedayati H, Khazaee T, Mogharrab M, Sharifzadeh GR. Prevalence of gestational diabetes mellitus and overt diabetes in perganant women in Birjand. Modern Care Journal. 2012;8(4):238-44.

4. Hirst JE, Tran TS, Do MAT, Morris JM, Jeffery HE. Consequences of gestational diabetes in an urban hospital in Viet Nam: a prospective cohort study. PLoS Med. 2012;9(7):e1001272. doi:10.1371/journal.pmed.1001272.

5. Deierlein AL, Siega-Riz AM, Chantala K, Herring AH. The association between maternal glucose concentration and child BMI at age 3 years. Diabetes Care. 2011;34(2):480-4. doi:10.2337/dc10-1766.

6. Aulinas A, Biagetti B, Vinagre I, et al. [Gestational diabetes mellitus and maternal ethnicity: high prevalence of fetal macrosomia in non-Caucasian women]. Medicina Clinica.
2013;141(6):240-5. doi:10.1016/j.medcli.2012.05.034.

7. Katon J, Reiber G, Williams MA, Yanez D, Miller E. Antenatal haemoglobin Alc and risk of large-for-gestational-age infants in a multi-ethnic cohort of women with gestational diabetes. Paediatr Perinat Epidemiol. 2012;26(3):208-17. doi:10.1111/j.1365-3016.2012.01266.x.

8. Cunningham F. leveno KJ, Bloom SL, Hauth JC, Rouse DJ, Spong CY. Abortion. In: Williams Obstetrics. New York: McGraw Hill; 2010.

9. Dode MA, dos Santos IS. Non classical risk factors for gestational diabetes mellitus: a systematic review of the literature. Cad Saude Publica. 2009;25:S341-S59.

10. Garcia-Vargas L, Addison SS, Nistala R, Kurukulasuriya D, Sowers JR. Gestational diabetes and the offspring: implications in the development of the cardiorenal metabolic syndrome in offspring. Cardiorenal Med. 2012;2(2):134-42. doi:10.1159/000337734.

11. Kim SY, England JL, Sharma JA, Njoroge T. Gestational diabetes mellitus and risk of childhood overweight and obesity in offspring: a systematic review. Exp Diabetes Res. 2011;2011:541308. doi:10.1155/2011/541308.

12. Philipps L, Santhakumaran S, Gale C, et al. The diabetic pregnancy and offspring BMI in childhood: a systematic review and meta-analysis. Diabetologia. 2011;54(8):195766. doi:10.1007/s00125-011-2180-y.

13. Ehrlich SF, Rosas LG, Ferrara A, et al. Pregnancy glucose levels in women without diabetes or gestational diabetes and childhood cardiometabolic risk at 7 years of age. J Pediatr. 2012;161(6):1016-21. doi:10.1016/j.jpeds.2012.05.049.

14. Bellamy L, Casas J-P, Hingorani AD, Williams D. Type 2 diabetes mellitus after gestational diabetes: a systematic review and meta-analysis. Lancet. 2009;373(9677):1773-9. doi:10.1016/S0140-6736(09)60731-5.

15. Kim C, Newton KM, Knopp RH. Gestational Diabetes and the Incidence of Type 2 Diabetes A systematic review. Diabetes Care. 2002;25(10):1862-8.

16. American Diabetes Association. Gestational diabetes mellitus. Diabetes Care. 2004;27(1):88-90.

17. Jones EJ, Appel SJ, Eaves YD, Moneyham L, Oster RA, Ovalle F. Cardiometabolic risk, knowledge, risk perception, and self-efficacy among American Indian women with previous gestational diabetes. J Obstet Gynecol Neonatal Nurs. 2012;41(2):246-57. doi:10.1111/j.1552-6909.2012.01339.x.

18. Albrecht SS, Kuklina EV, Bansil P, et al. Diabetes trends among delivery hospitalizations in the US, 1994-2004. Diabetes Care. 2010;33(4):768-73. doi:10.2337/dc09-1801.

19. ADA. Position statement. Diagnosis and classification of diabetes mellitus. Diabetes Care. 2010;33:62-9.

20. Shahbazian N, Shahbazian H, Kashkouli S, Moravaj AA. Prevalence and risk factors of diabetes mellitus, impaired glucose tolerance and impaired fasting glucose in patients with gestational diabetes in Ahvaz Imam Khomeini hospital. IJOGI. 2013;16(59):1-5.

21. Larijani M, Azizi F, Bastanhagh M, Pazhohi M, Hosseinnejad A. Prevalence of gestational diabetes in young women. Journal of Endocrine and Metabolism. 2002;4(1):23-7. [Persian].

22. Navayi L, Kimiagar M, Kheirkhahi M, Azizi F. Investigating diabetes epidemiology among pregnant women in Tehran province villages. Pajouhesh Dar Pezeshki. 2002;26(3):22317 [Persian].

23. Karimi F, Nabipour I, Jafari M, Ghamzadeh F. Selective screening of gestational diabetes based on $50 \mathrm{~g}$ glucose in 
Boshehr pregnant women. Iranian Journal of Diabetes and Lipid. 2001;2(1):45-51. [Persian].

24. Keshavarz M. Prevalence of gestational diabetes in urban area of Shahroud 1999-2000. J Mazandaran Univ Med Sci. 2003;13(41):90-7. [Persian].

25. Atashzadeh Shorideh F. Frequency of gestational diabetes and its related factors in pregnant women attended to Tehran University of Medical Sciences obstetrics and gynecology clinics 2000-2001. J Rafsanjan Univ Med Sci. 2006;5(3):175-80. [Persian].

26. Hosseinnejad A, Larijani M. Clinical and laboratory findings in glucose tolerance during pregnancy. . Iranian Journal of Diabetes and Lipid. 2003;2(2):131-44. [Article in Persian].

27. Hadaegh F, Khirandish M, Shafeiee R, Tohidi M. Prevalence of gestational diabetes in Bandarabbas pregnant women. Journal of Endocrine and Metabolism. 2004;6(3):225-33. [Article in Persian].

28. Tabatabaiee A, Falah Z, Haghighi S, Farmani M, Horri N, Eslamian Z. Prevalence and risk factors of gestational diabetes in Isfahan Pregnant women. Iranian Journal of Endocrinology and Metabolism. 2007;9(3):251-9. [Persian].

29. Rahimi G. Prevalence of gestational diabetes in pregnant women referring to gynecology and obstetrics clinics in Ardabil. Journal of Ardabil University of Medical Sciences . 2003;4(13):32-8. [Persian].

30. Hematyar M, Khabiri M. Prevalence of gestational diabetes and comparison of mean maternal age in healthy and gestational diabetic patients at Javaheri hospital (20032006). J Qazvin Univ Med Sci. 2008;12(1):69-73. [Persian].

31. Shahbazian H, Shahbazian N, Yarahmadi M, Saiedi S. Prevalence of gestational diabetes mellitus in pregnant women referring to gynecology and obstetrics clinics. Jundishapur Sci Med J. 2012;11(2):113-21. [Persian].

32. Garshasbi A, Faghih Zadeh S, Falah N, et al. Evaluation of selective screening for diagnosis of gestational diabetes mellitus. Tehran Univ Med J. 2009;67(4):290-5.

33. Rahimi MA, Najafi F. Prevalence of pregnancy diabetic and its related risky signs in Kermanshah pregnant women in 2007. J Kermanshah Univ Med Sci 2010;4(3):244-50. [Persian].

34. Mir Feizi M, Azarian A, Mir Heydari M. Prevalence and risk factors of gestational diabetes in Karaj pregnant women J Sugar Lipid Iran. 2010;9(4):376-82. [Persian].

35. Mohajerani Tehrani M, Parvizi M, Amini Moghadam S, et al. Increased prevalence of polycystic ovary syndrome in women with a history of gestational diabetes. Iranian Journal of Diabetes and Lipid. 2010;9(4):350-44. [Persian].

36. BoozariZ, Yazdani S, Abedi Samakoosh M, Mohammadnataj M, Emami Meibodi S. Prevalence and risk factors of gestational diabetes in pregnant women referred to health centers - city of Babol, from September 2010 to March 2011. IJOGI. 2013;16(43):6-13. [Persian].

37. Goli M, Firouzeh F. Prevalence of gestational diabetes and efficacy of risk factors in screening of referrals to health centers. Holistic Nursing and Midwifery Journal. 2014;25(73):56-63 [Article in Persian].

38. Mohammadzade F, Mobasheri E, Eshghinia S, Kazeminedhad V, Vakili M. Prevalence and risk factors of gestational diabetes in Gorgan Pregnant women in 20112012. J Sugar Lipid Iran. 2012;12(3):204-10. [Article in Persian].

39. Moradi S, Shafieepour MR, Mortazavi M, Pishgar F.
Prevalence of gestational diabetes mellitus in Rafsanjan: a comparison of different criteria. Med J Islam Repub Iran. 2015;29:209.

40. Dorostkar H, Zomorodi Zare N, Alikhani Mahvar A, Goodarzi M. Prevalence of gestational diabetes mellitus in different age groups in Razan, Iran 2014. J Mazandaran Univ Med Sci 2015;25(127):74-81. [Persian].

41. Mohammadpour-Dehaki R, Shahdadi H, Shamsizadeh $\mathrm{M}$, Forghani F. Prevalence of gestational diabetes and risk factors in pregnant women referring to health center in Zabol city. J Zabol Univ Med Sci. 2015;3(7): 1-13. [Persian].

42. Tobia D, Zhang C, van Dam R, Bowers K, Hu F. Physical activity before and during pregnancy and risk of gestational diabetes mellitus: a meta-analysis. Diabetes Care. 2011;34(1):223-9. doi:10.2337/dc10-1368.

43. Taber L. Gestational diabetes: is it preventable? Am J Lifestyle Med. 2012;6:395-40.

44. Pirc LK, Owens JA, Crowther CA, Willson K, De Blasio MJ, Robinson JS. Mild gestational diabetes in pregnancy and the adipoinsular axis in babies born to mothers in the ACHOIS randomised controlled trial. BMC Pediatr. 2007;7:18. doi:10.1186/1471-2431-7-18.

45. Hjelm K, Berntorp K, Frid A, Åberg A, Apelqvist J. Beliefs about health and illness in women managed for gestational diabetes in two organisations. Midwifery. 2008;24(2):16882. doi:10.1016/j.midw.2006.12.008.

46. Seshiah V, Balaji V, Balaji MS, Paneerselvam A, Kapur A. Pregnancy and diabetes scenario around the world: India. Int J Gynaecol Obstet. 2009;104:S35-S8. doi:10.1016/j. ijgo.2008.11.035.

47. Seshiah V, Balaji V, Balaji MS, Sanjeevi C, Green A. Gestational diabetes mellitus in India. J Assoc Physicians India. 2004;52:707-11.

48. Salihu HM, Emusu D, Aliyu MH, Kirby RS, Alexander GR. Low maternal age and neonatal survival of extremely preterm twins (20-28 weeks of gestation). Obstet Gynaecol. 2004;103(6):1246-54. doi:10.1097/01. AOG.0000126724.91988.fa.

49. Ozalp S, Tanir HM, Sener T, Yazan S, Keskin AE. Health risks for early $(\leq 19)$ and late $(\geq 35)$ childbearing. Arch Gynecol Obstet. 2003;268(3):172-4. doi:10.1007/s00404002-0359-7.

50. Fadaei B, Movahedi M, Akbari M, Ghasemi M, Jalalvand A. Effect of maternal age on pregnancy outcome. J Isfahan Med Sch. 2011;29(145):855-60. [Persian].

51. Anzaku AS, Musa J. Prevalence and associated risk factors for gestational diabetes in Jos, North-central, Nigeria. Arch Gynecol Obstet. 2013;287(5):859-63. doi:10.1007/s00404012-2649-z

52. Zargar AH, Sheikh MI, Bashir MI, et al. Prevalence of gestational diabetes mellitus in Kashmiri women from the Indian subcontinent. Diabetes Res Clin Pract. 2004;66(2):139-45. doi:10.1016/j.diabres.2004.02.023

53. O'Sullivan E, Avalos G, O'Reilly M, et al. The prevalence and consequences of gestational diabetes in Ireland. Ir Med J. 2012;105(5):13-5.

54. Soheilykhan S, Mogibian M, Rahimi S, Rashidi M. Incidence of gestational diabetes mellitus in pregnant women. Iran J Reprod Med. 2010;8(4):24-5.

55. Tohidi M, Kalantar-Hormozi M, Adinehpour A, Dabbaghmanesh M, Siadatian J, Ranjbar Aormani G. Prevalence of overweight and obesity in adults in the city of Shiraz in2008. Iran J Diabetes Metab. 2009:43-8. 
56. Kim JH, Shin HS, Park BK, Yang KM, Lee YH, Ryu HM. Impact of prepregnancy body mass index on pregnancy outcome in women with a singleton conceived by assisted reproductive technology and spontaneously conceived pregnancy: a case-control study. J Korean Acad Nurs. 2012;42(4):517-24. doi: 10.4040/jkan.2012.42.4.517.

57. Aksornphusitaphong A, Phupong V. Risk factors of early and late onset pre-eclampsia. J Obstet Gynaecol Res. 2013;39(3):627-31. doi:10.1111/j.1447-0756.2012.02010.x

58. Nanjundan P, Bagga R, Kalra J, Thakur J, Raveendran A. Risk factors for early onset severe pre-eclampsia and eclampsia among north Indian women. J Obstet Gynaecol. 2011;31(5):384-9. doi:10.3109/01443615.2011.566389

59. Huda S, Brodie L, Sattar N. Obesity in pregnancy: prevalence and metabolic consequences. Semin Fetal Neonatal Med. 2010;15(2):70-6

60. Shelia G, Beshkenadze M. [Body mass of pregnant females, as a risk factor for the development of obstetric complications]. Georgian Medical News. 2012;211:14-7.

61. Cedergren M. Effects of gestational weight gain and body mass index on obstetric outcome in Sweden. Int J Gynecol Obstet. 2006;93(3):269-74. doi:10.1016/j.ijgo.2006.03.002.

62. Ducarme G, Rodrigues A, Aissaoui F, Davitian C, Pharisien I, Uzan M. [Pregnancy in obese patients: which risks is it necessary to fear?]. Gynecol Obstet Fertil. 2007;35(1):1924. doi:10.1016/j.gyobfe.2006.10.029.

63. Kitzmiller JL. Cost analysis of diagnosis and treatment of gestational diabetes mellitus. Clin Obstet Gynecol. 2000;43(1):140-53.

64. ADA. Gestational diabetes mellitus. Diabetes Care. 2003;26:103-5. doi:10.2337/diacare.26.2007.S103.

65. Hossein-Nezhad A, Larigani B, Bastanhagh M, Pajouhi M. Gestational diabetes mellitus: prevalence, risk factors, maternal and infant outcomes. Abstract book of the 12th AOCE; 2002.

66. Irving RR, Mills JL, Choo-Kang EG, et al. The burden of gestational diabetes mellitus in Jamaican women with a family history of autosomal dominant type 2 diabetes. Revista Panamericana de Salud Publica. 2008;23(2):85-91. doi:10.1590/S1020-49892008000200003

67. Johns K, Olynik C, Mase R, Kreisman S, Tildesley H. Gestational diabetes mellitus outcome in 394 patients. J Obstet Gynaecol Can. 2006;28(2):122-7. doi:10.1016/ S1701-2163(16)32068-0.

68. Harder T, Franke K, Kohlhoff R, Plagemann A. Maternal and paternal family history of diabetes in women with gestational diabetes or insulin-dependent diabetes mellitus type I. Gynecol Obstet Invest. 2001;51(3):160-4. doi:10.1159/000052916.

69. Chan LYS, Wong SF, Ho LC. Diabetic family history is an isolated risk factor for gestational diabetes after 30 years of age. Acta Obstet Gynecol Scand. 2002;81(2):115-7. doi:10.1034/j.1600-0412.2002.810205.x

70. Cheung N, Wasmer G, Al-Ali J. Risk for gestational diabetes among Asian women. Diabetes Care. 2001;24:955-6.

71. Svare J, Pedersen H, Pedersen L. Perinatal complications in women with gestational diabetes mellitus. Acta Obstet
Gynecol Scand. 001;80(10):899-904.

72. Saldana TM, Siega-Riz AM, Adair LS, Savitz DA, Thorp JM. The association between impaired glucose tolerance and birth weight among black and white women in central North Carolina. Diabetes Care. 2003;26(3):656-61.

73. Hernández-Herrera R, Castillo-Martínez N, Banda-Torres ME, Alcalá-Galván G, Tamez-Pérez HE, Forsbach-Sanchez G. Hypoglycemia in the newborns of women with diabetes mellitus]. Rev Invest Clin. 2005;58(4):285-8.

74. Cunningham F. William's Obstetrics. 22rd ed. New York: McGraw-Hill; 2005.

75. Lalooha F, Elmizadeh K, Javadi A, Ghaleh T, Krmanshahi B. Association between abnormal glucose challenge test and pregnancy outcome. J Zanjan Univ Med Sci. 2012;20(83):53-61. [Persian].

76. Elmizadeh K, Javadi A, Dabbaghi Ghaleh T, Kermanshahi B. Association between abnormal glucose challenge test and pregnancy outcomes. ZUMS Journal. 2012;20(83):53-61.

77. Bastani F, Zarrabi R. Correlations of self-efficacy among women with gestational diabetes. Journal of Hayat. 2011;16(3):56-65. [Persian].

78. Pedrosa RP, Drager LF, Gonzaga CC, et al. Obstructive sleep apnea the most common secondary cause of hypertension associated with resistant hypertension. Hypertension. 2011;58(5):811-7.

79. Roberts CL, Ford JB, Algert CS, et al. Population-based trends in pregnancy hypertension and pre-eclampsia: an international comparative study. BMJ Open. 2011;1(1):e000101. doi:10.1136/bmjopen-2011-000101.

80. Dehghani Firoozabadi R, Tayebi N, Falahatian V. Correlation between blood pressure and urine $\mathrm{Ca} / \mathrm{Cr}$ Ratio with preeclampsia in nullipara women. J Babol Univ Med Sci. 2007;9(4):47-5. [Persian].

81. Rose B, Post T. Clinical Physiology of Acid-Base and Electrolyte Disorders. 5th ed. New York: McGraw-Hill; 2001.

82. Solomon CG, Willett WC, Carey VJ, et al. A prospective study of pregravid determinants of gestational diabetes mellitus. JAMA. 1997;278(13):1078-83. doi:10.1001/ jama.1997.03550130052036.

83. Xiong X, Saunders L, Wang F, Demianczuk N. Gestational diabetes mellitus: prevalence, risk factors, maternal and infant outcomes. Int J Gynecol Obstet. 2001;75(3):221-8. doi:10.1016/S0020-7292(01)00496-9.

84. Santos-Ayarzagoitia M, Salinas-Martínez AM, VillarrealPérez JZ. Gestational diabetes: validity of ADA and WHO diagnostic criteria using NDDG as the reference test. Diabetes Res Clin Pract. 2006;74(3):322-8. doi:10.1016/j. diabres.2006.04.005.

85. Lu GC, Luchesse A, Chapman V, Cliver S, Rouse DJ. Screening for gestational diabetes mellitus in the subsequent pregnancy: Is it worthwhile? Am J Obstet Gynecol. 2002;187(4):918-21. doi:10.1067/mob.2002.126979.

86. Cheung NW, Wasmer G, Al-Ali J. Risk factors for gestational diabetes among Asian women. Diabetes Care. 2001;24(5):955-6. doi:10.2337/diacare.24.5.955.

Copyright $\odot 2017$ The Author (s); This is an open-access article distributed under the terms of the Creative Commons Attribution License (http://creativecommons.org/licenses/by/4.0), which permits unrestricted use, distribution, and reproduction in any medium, provided the original work is properly cited. 